\title{
THE ASEAN WITHOUT A CUSTOMS UNION OR A SINGLE MARKET: CONSEQUENCES OF THE ASEAN ECONOMIC COMMUNITY BLUEPRINT 2025
}

\author{
Moh Firstananto Jerusalem \\ International Studies, Graduate School of Asia Pacific Studies, Waseda University, \\ Japan \\ Email: firstananto@gmail.com
}

\author{
ARTICLE INFORMATION \\ Received date \\ [05-05-2020] \\ Revision \\ [17-06-2020] \\ Accepted date \\ [25-06-2020]
}

\begin{abstract}
:
In the 2015 Association of Southeast Asian Nations (ASEAN) Economic Community (AEC) blueprint, the term 'single market' was used as a goal of the economic community. Theoretically, a single market is a level of economic integration beyond a customs union. Under that blueprint, a customs union would have a chance to be established as a necessary prerequisite for a single market. However, the new 2025 blueprint does not adopt a single market concept. Different terms have been introduced, namely integrated and cohesive economy' and 'unified market.' This article assesses the economicintegration concept adopted by the AEC blueprint using a content analysis methodology. The method reviews the changes of concepts by using economic-integration theory to indicate the patterns and direction of the goal of the economic community. The finding is that the change of terms reflects the change of concept; that is, the AEC is pursuing a different direction for economic integration. Therefore, under the 2025 blueprint, ASEAN will not proceed to a customs union and single market and will remain at the free-tradearea level. Additionally, ASEAN will not be a closed trade block but instead will tend toward open regionalism in relation to non-ASEAN countries or regions.
\end{abstract}

Keywords: ASEAN Economic Community, Customs Union, Single Market, Economic Integration, Open Regionalism. 


\section{INTRODUCTION}

The 2025 AEC blueprint revised the 2015 AEC blueprint, a major change being the elimination of the term 'single market.' Another term, 'unified market,' is introduced under 'a highly integrated and cohesive economy' scheme (ASEAN Secretariat, 2015). Understanding this phenomenon should reveal the reasons and circumstances behind the change, especially whether the elimination of the term 'single market' and the introduction of the term 'unified market' reflects a change to the concept of economic integration in the Association of Southeast Asian Nations (ASEAN). This introduces concerns regarding the consequences for the new AEC blueprint. This study investigates these queries through a conceptual approach utilizing economic integration theories as conceptual benchmarks and content analysis as a methodology for examining the contents of the blueprints.

A previous conceptual study of the AEC was based on the 2015 blueprint. Pelkmans (2016) discussed the AEC through analyzing 'Roadmap for an ASEAN Community 2009-2015', which contains the 2015 AEC blueprint. That study reviewed the AEC using a conceptual approach. It covers topics such as the fundamentals and stages of economic integration and the conceptual foundation of the AEC with regard to the concepts of free flow, an ASEAN single market and production base. Pelkmans' study aimed to make the ASEAN economic integration model clearer, concluding that the ASEAN model of economic integration is conceptually challenged by observing two stylized economic integration approaches: the European Union (EU) model and the classical free-trade area (FTA). The ASEAN does not want to pursue either one model: the EU model is supranational, which would not be suitable, but, at the same time, the ASEAN wants to proceed beyond an FTA. Therefore, the AEC adopted two concepts in parallel: the 'single market' and the 'production base.'

This paper reassesses the AEC by comparing the 2025 blueprint to the 2015 blueprint. This research offers a new understanding of ASEAN economic integration by examining the concept of economic integration adopted in the new AEC blueprint. This study derives value from exploring the conceptual background of the new AEC blueprint to recognize the patterns of regionalism and the direction of future economic integration. 
Moreover, discourse about the concept of economic integration in the ASEAN is still limited in comparison to EU studies. Thus, in focusing on the concept of economic integration adopted in the AEC blueprint, this study contributes academically by enriching discussion about regional economic integration in the ASEAN context. Additionally, it is necessary to update ASEAN studies due to dynamic changes in southeast Asia. In terms of policy, this research contributes ideas to be considered by national leaders and officials of ASEAN member states in the process of economicintegration policymaking.

The paper comprises the following four sections: the next section is the literature review, which details relevant previous studies; Section 3 describes the methodology employed to analyze the problem statements; Section 4 delivers analysis and discussion; Section 5 presents the conclusion.

\section{LITERATURE REVIEW}

To understand the elimination of the term 'single market' and the introduction of the term 'unified market,' the theory of economic integration was reviewed because the term 'single market' belongs to economic-integration theory. This literature review describes selected economic integration theories that have been used in previous studies and elaborated for the current study. These theories will be employed to analyze the phenomenon and understand the AEC's integration model.

The literature review uses the theory of economic integration described by Balassa (1961), who distinguished economic integration into stages based on a process eliminating the distinction between national economies. It includes five consecutive processes: (i) FTA; (ii) customs union; (iii) common market; (iv) economic union; (v) complete economic integration. ${ }^{1}$ To distinguish these steps, it is necessary to define each step. First, at the FTA level, tariffs and quotas between member countries are eliminated. However, FTA members still control their own tariffs towards nonmembers. Second, a customs union eliminates discrimination regarding the movement of commodities between participating countries and implements equal tariffs for external trade. This equal

\footnotetext{
1 Balassa also used the term 'total economic integration' to explain the term 'complete economic integration.'
} 
tariff is currently known as a common external tariff(CET). Thus, the distinction between a customs union and FTA is a CET. An FTA does not implement a CET. Thus, a customs union is an FTA with CET implementation.

The third step is the establishment of a common market eliminating restrictions on both trade and factor movements. The fourth step is the incorporation of a common market harmonizing national economic policies to abolish discrimination caused by policy disparities to reach economic union level. Finally, complete economic integration is reached by developing uniform monetary, fiscal, social, countercyclical policies and establishing a supranational authority that can make legally binding decisions for all members. Table 1 represents Balassa's economic-integration scheme.

Table 1

Balassa's Economic-Integration Scheme

\begin{tabular}{|l|c|c|c|c|c|}
\hline \multicolumn{1}{|c|}{ Stage } & $\begin{array}{c}\text { Tarif and } \\
\text { Quota } \\
\text { Abolished }\end{array}$ & $\begin{array}{c}\text { Common } \\
\text { External } \\
\text { Tariff }\end{array}$ & $\begin{array}{c}\text { Free } \\
\text { Factor } \\
\text { Movement }\end{array}$ & $\begin{array}{c}\text { National } \\
\text { Policies } \\
\text { Harmonization }\end{array}$ & $\begin{array}{c}\text { Monetary, } \\
\text { Fiscal, } \\
\text { Social, } \\
\text { Supranational } \\
\text { Authority }\end{array}$ \\
\hline FTA & Yes & No & No & No & No \\
\hline $\begin{array}{l}\text { Customs } \\
\text { Union }\end{array}$ & Yes & Yes & No & No & No \\
\hline $\begin{array}{l}\text { Common } \\
\text { Market }\end{array}$ & Yes & Yes & Yes & No & No \\
\hline $\begin{array}{l}\text { Economic } \\
\text { Union }\end{array}$ & Yes & Yes & Yes & Yes & No \\
\hline $\begin{array}{l}\text { Complete } \\
\text { Economic } \\
\text { Integration }\end{array}$ & Yes & Yes & Yes & Yes & Yes \\
\hline
\end{tabular}

Source: Author's summary based on Balassa's theory of economic integration.

Another scholar, El-Agraa (2011), proposed an idealistic integration scheme. ElAgraa added political integration as a further step after 'complete economic integration.' In that model, the stages are (i) FTA; (ii) customs union; (iii) common market; (iv) complete economic union; (v) complete political union. Table 2 describes El-Agraa's economic-integration scheme. 
Table 2

El-Agraa's Economic-Integration Scheme

\begin{tabular}{|l|c|c|c|c|c|}
\hline Scheme & $\begin{array}{c}\text { Free- } \\
\text { intra } \\
\text { Scheme } \\
\text { Trade }\end{array}$ & $\begin{array}{c}\text { Common } \\
\text { Commercial } \\
\text { Policy }\end{array}$ & $\begin{array}{c}\text { Free } \\
\text { Factor } \\
\text { Mobility }\end{array}$ & $\begin{array}{c}\text { Common } \\
\text { Monetary and } \\
\text { Fiscal Policy }\end{array}$ & $\begin{array}{c}\text { One } \\
\text { Government }\end{array}$ \\
\hline FTA & Yes & No & No & No & No \\
\hline $\begin{array}{l}\text { Customs } \\
\text { Union }\end{array}$ & Yes & Yes & No & No & No \\
\hline $\begin{array}{l}\text { Common } \\
\text { Market }\end{array}$ & Yes & Yes & Yes & No & No \\
\hline $\begin{array}{l}\text { Complete } \\
\text { Economic } \\
\text { Union }\end{array}$ & Yes & Yes & Yes & Yes & Yes \\
\hline $\begin{array}{l}\text { Complete } \\
\text { Political } \\
\text { Union }\end{array}$ & Yes & Yes & Yes & Yes & \\
\hline
\end{tabular}

Source: El-Agraa, 2011, p. 2.

Based on Tables 1 and 2, both Balassa and El-Agraa agree on the meaning of an FTA, a customs union and the common market. They differ on some points, however. According to El-Agraa, a complete economic union is a common market with uniform monetary and fiscal policies created by establishing a central authority to create and control these policies; he does not distinguish between a 'economic union' and 'complete economic integration.'While El-Agraa uses the term 'complete economic union' to incorporate single monetary and fiscal policy in the common market, he does not include a social aspect in the definition of a complete economic union; Balassa considers this a component of complete economic integration. However, El-Agraa did add the step of 'complete political union,' occurring when member nations become one nation with a central authority, including a parliament and the institutions of a sovereign state. This term means two or more nations become one state under one government, an example being the 1990 unification of Germany. El-Agraa considers political union motivated by geographical grouping and political concerns to produce economic integration (El-Agraa, 2011).

Thus, though Balassa's version is regarded as a cornerstone in the theory of economic integration (Hosny, 2013), El-Agraa contributed an additional step in the understanding of economic integration. Nonetheless, both economic integration theories 
developed from the same regional context of the developed nations of western Europe. The application of economic-integration theory is complicated by implementation in developing regions, leading to proposals of challenges to the traditional theories. First, the concept of trade creation and trade diversion in customs unions: in the conventional economic-integration theory, customs unions trigger trade creation and trade diversion. Trade creation describes trade moving between high-cost suppliers in member states and low-cost suppliers in other member states, while trade diversion describes trade shifting between low-cost suppliers from outside the union and high-cost suppliers inside the union. These phenomena might result from a CET protecting high-cost suppliers inside the customs union. This traditional theory regards trade creation as having a beneficial impact on the participating countries and trade diversion as having a harmful effect. In other words, trade creation increases welfare, while trade diversion decreases welfare (Viner, 1950).

In contrast, Andic, Andic and Dosser (1971) argued that trade creation and trade diversion might be both beneficial and harmful elements, claiming that trade creation and trade diversion are misleading terms in the developing-countries context. They describe an adjusted customs union as maximizing development creation and minimizing development diversion. Unlike conventional customs unions, which implement complete trade freedom between participating countries and a CET, the approach they formulated examined each sector or commodity, ultimately suggesting that some sectors would have free trade with the rest of the world, while other sectors, especially common industries, would also have free trade within the union. Therefore, the modified customs union for developing countries is based on a sector-by-sector examination.

Second, recent conceptual studies of economic integration consider positive integration. ${ }^{2}$ Pelkmans (2016) challenged Balassa's theory, which considers positive integration beginning with an economic union; Pelkmans argues that positive integration could be initiated at the FTA level and subsequently proposed six adjusted steps to

\footnotetext{
2 'Positive integration refers to joint action by member states' in terms of economic cooperation, employing common economic instruments and common regulations, and establishing common institutions delegating power. See Pelkmans (2016), p. 19.
} 
describe modern market integration: (i) FTA; (ii) customs union; (iii) FTA-plus (or customs union-plus); (iv) deep and comprehensive FTAs or customs unions; (v) common market; (vi) single market. Pelkmans' definition of an FTA and a customs union are generally similar to Balassa and El-Agraa's versions. However, FTA-plus, customs union-plus and deep-and-comprehensive FTAs or customs unions have been introduced into this concept of modern market integration. The FTA-plus or customs union-plus stage considers not only tariff and quota abolishment but also other trade aspects described in agreements such as the General Agreement on Tariff and Trade, the General Agreement on Trade in Services, and Trade-Related Aspects of Intellectual Property Rights agreement. In terms of modern market integration, the FTA-plus or customs unionplus stage incorporates obligations included in many World Trade Organization agreements, such those regarding agriculture, sanitary and phytosanitary barriers, technical barriers to trade, trade-related investment measures, anti-dumping, textiles, clothing, customs valuation, pre-shipment inspection, rule of origin, import licencing, subsidies and countervailing duties, and safeguards. At this stage, market integration is typically accompanied by soft economic cooperation, including voluntary policy emulation or best-practice-leadership efforts. Additionally, deep-and-comprehensive FTAs or customs unions are characterized by a specific range of policy domains, including service, positive integration, and equivalence as a way of avoiding or reducing sanitary, phytosanitary and technical barriers to trade.

Furthermore, Pelkmans' version of market integration distinguishes the common market from the single market. Generally, Pelkmans' version of the common market is similar to Balassa and El-Agraa's versions, comprising free-market access to goods, services, labour and capital. In the common market, member states ensure free market access through a combination of positive and negative integration processes. ${ }^{3}$ Finally, a single market is an economic concept in which the fifth market, codified technology and knowledge (such as intellectual property right), is incorporated into the four common markets of goods, services, labour and capital. Therefore, a single market combines

\footnotetext{
3 'Negative integrations refers to cross-border (intra-group) liberalization of market access'; examples include removal of discrimination and barriers at borders and within the group. See Pelkmans (2016), p. 19.
} 
deeper, wider and more far-reaching negative and positive integration processes, with the fundamental obligation of ensuring access to the five common markets.

\section{RESEARCH METHODS}

This study uses content analysis to analyze the AEC blueprints. Content analysis is 'a research technique for making replicable and valid inferences from texts (or other meaningful matter) to the contexts of their use' (Krippendorff, 2019, p. 24). Its objective is 'to provide knowledge and understanding of the phenomenon under study' (DowneWamboldt, 1992, p. 314). The techniques are described in detail in the following subsections.

\subsection{Selecting Unit of Analysis}

The starting point for content analysis is selecting the unit of analysis. For example, the unit could be 'words, sentences, phrases, paragraphs, or whole text such as interviews, diaries, or books; themes (entire ideas or thoughts); and the amount of space and time given to a topic' (Downe-Wamboldt, 1992, p. 315). The term 'text' is 'merely a matter of convenience and of habit' because 'text' is used as 'a generic term' covering all forms of qualitative material (Schreier, 2012, p. 3).

\subsection{Determining Coding Framework through Directed or Deductive Approach}

The coding framework is a way of structuring material, consisting of 'main categories specifying relevant aspects and of subcategories for each main category specifying relevant meanings concerning this aspect' (Schreier, 2012, p. 61). This study's coding framework used existing theory through directed content analysis because it offered more structural framework (Hickey \& Kipping, 1996). The directed approach validates a theoretical framework or theory and extends it conceptually. It has been regarded as a deductive approach because it can predict the variables of interest or the relationships among variables. This approach can determine the initial coding scheme or relationships between codes (Mayring, 2000). The deductive approach begins with theory. The theory can assist in designing a coding scheme focused on the concept. A coding framework is developed according to how the theory defines the concept. Therefore, theory is very important for the design of the content analysis (Folger, Hewes, \& Poole, 1984). Additionally, the ability to predict the relationship between variables 
comes from using existing theory due to its usefulness in developing the research question. The researcher can begin the analysis by using existing theory to identify key concepts and use them as initial coding categories (Potter \& Levine-Donnerstein, 1999).

\subsection{Employing Qualitative Content Analysis: Conceptual and Relational}

Qualitative content analysis is 'a method for describing the meaning of qualitative material in a systematic way' (Schreier, 2012, p.1), a definition fitting the objective of this research because content analysis deals with the less obvious meanings of a text (Schreier, 2012). To analyze the less obvious meanings of the text, two content analysis strategies were employed: a conceptual analysis and a relational analysis. The conceptual analysis determined the presence of words or concepts in a text or set of texts. A relational analysis concerns not only the presence of concepts in the text but also the relationships between concepts. A concept can be extracted and categorized into two types: explicit concepts and implicit concepts (Carley, 1994). Qualitative content analysis is regarded as a systematic method for interpreting the content of a text because it uses a classificationbased coding process and identifies themes or pattern (Hseih \& Shannon, 2005). Therefore, this approach best suits this research because it can be used to identify the patterns of ASEAN economic integration.

\section{ANALYSIS AND DISCUSSION}

There were several steps to this research. First, the 2015 and 2025 AEC blueprints were determined to be the units of analysis. Using economic-integration theory, essential concepts or terms were used to build the coding framework to observe a concept's presence in both blueprints. Then, both blueprints were compared to distinguish the changes and differences between them by identifying the main characteristics. The comparison moved from general items to specific items.

Second, after finding differences between blueprints, the applied concepts indicated in both blueprints were compared to the theories of economic integration. This comparison was designed to determine the gap between theory and practice by utilizing a coding framework based on the ASEAN context. This enabled customs union and single market concepts to be determined in both blueprints through inference or interpretation 
according to conceptual and relational analysis considering two types of extraction: explicit concepts and implicit concepts.

Third, current ASEAN economic integration was compared to EU economic integration to identify the general differences, patterns and directions of the AEC. This comparative regionalism draws a broad overview of the direction of ASEAN economic integration.

\subsection{Comparing the 2015 and 2025 AEC Blueprints: Unit of Analysis and Coding Framework}

This paper focuses on the first three steps in economic integration: FTA, customs union and the single or common market. This is because the AEC blueprints don't describe integration beyond the single market. Steps such as economic union, total economic integration, complete economic union and complete political union are not yet considered relevant in the ASEAN context, perhaps due to their current lack of feasibility. This study regards concepts such as FTA-plus, customs union-plus and deep-andcomprehensive FTAs or customs unions as belonging to the FTA and customs-union clusters. For coding purposes, this study uses the term 'single market' to describe the advance of the common market because both the ASEAN and the EU utilize the term. The EU did previously use the term 'common market' on the basis of the 1957 Rome Treaty, which established the European Economic Community. However, the EU has used the term 'single market' since the 1986 Single European Act, the first major revision of the Treaty of Rome. The ASEAN has used the term 'single market' since the 2015 AEC blueprint.

To begin the content analysis, selected terms or concepts derived from economicintegration theory were determined: 'FTA', incorporating rule of origin, a 'customs union' that includes a CET, and 'single market', including the concept of free flow. Using a directed or deductive approach, these concepts were used to determine the coding framework. The comparison between the blueprints to identify their underlying concepts is described in the following paragraphs.

On the 20th of November, 2007, the ASEAN officially declared its economic community blueprint. The declaration was signed by top national leaders of its member 
states. This 2015 AEC blueprint features certain key interrelated and mutually reinforcing characteristics: (i) a single market and production base, (ii) a highly competitive economic region, (iii) a region of equitable economic development, and (iv) a region fully integrated into the global economy (ASEAN Secretariat, 2008).

In 2015, the ASEAN developed an update to the old blueprint, which would expire by the end of 2015. Leaders of ASEAN adopted the new 2025 AEC blueprint at the 27th ASEAN Summit in Kuala Lumpur on the 22nd of November, 2015. The new blueprint provides strategic measures for the period between 2016 and 2025 with the aim of achieving AEC by 2025. The 2025 AEC blueprint also features interrelated and mutually reinforcing characteristics. However, there are significant changes to the wording: (i) a highly integrated and cohesive economy; (ii) a competitive, innovative and dynamic ASEAN; (iii) enhanced connectivity and sectoral cooperation; (iv) a resilient, inclusive, people-oriented and people-centred ASEAN; (v) a global ASEAN.

In general, the comparison between the two blueprints involved three steps, moving from general observations to consideration of specific items related to the customs union and the single market. Tables 3, 4 and 5 present the three stages of comparison. Table 3 compares the general characteristics of the AEC in each blueprint. Table 4 compares elements of the first of the general characteristics, given it considers the customs union and single market concepts and is thus highly relevant for this study. Table 5 compares specific elements related to the free flow of goods in relation to tariff policies within the customs union as a prerequisite for the development of a single market.

Table 3

A Comparison of General Characteristics of the 2015 and 2025 AEC Blueprints

\begin{tabular}{|l|l|}
\hline \multicolumn{1}{|c|}{ 2015 AEC Blueprint } & \multicolumn{1}{c|}{ 2025 AEC Blueprint } \\
\hline $\begin{array}{l}\text { 1. A single market and production } \\
\text { base }\end{array}$ & $\begin{array}{l}\text { 1. A highly integrated and cohesive } \\
\text { economy }\end{array}$ \\
$\begin{array}{l}\text { 2. A highly competitive economic } \\
\text { region }\end{array}$ & $\begin{array}{l}\text { 2. A competitive, innovative, and dynamic } \\
\text { ASEAN }\end{array}$ \\
$\begin{array}{l}\text { 3. A region of equitable economic } \\
\text { development }\end{array}$ & $\begin{array}{l}\text { 3. Enhanced connectivity and sectoral } \\
\text { cooperation }\end{array}$ \\
$\begin{array}{l}\text { 4. A region fully integrated into } \\
\text { the global economy }\end{array}$ & $\begin{array}{l}\text { 4. A resilient, inclusive, people-oriented, } \\
\text { and people-centred ASEAN }\end{array}$ \\
& 5. A global ASEAN \\
\hline
\end{tabular}

Source: Official Documents of the 2015 and 2025 AEC Blueprints 
After reviewing the characteristics of the AEC blueprints for 2015 and 2025, the relevant items for this study were identified as falling under the umbrella of the first characteristic. The other characteristics are not discussed further. Thus, this study focuses on the 2015 blueprint's description of 'a single market and production base' in comparison to the 2025 blueprint's description of 'a highly integrated and cohesive economy.' Table 4 represents this comparison.

Table 4

Details of the 2015 and 2025 AEC Blueprints' Conception of the ASEAN Market Integration

\begin{tabular}{|c|c|}
\hline $2015 A$ & nt \\
\hline $\begin{array}{c}\text { 'A single market and production } \\
\text { base' }\end{array}$ & $\begin{array}{l}\text { 'A highly integrated and cohesive } \\
\text { economy' }\end{array}$ \\
\hline $\begin{array}{l}\text { Term 'single market' with the } \\
\text { 'free flow' concept described with } \\
\text { the following five core elements: } \\
\text { 1. Free flow of goods } \\
\text { 2. Free flow of services } \\
\text { 3. Free flow of investment } \\
\text { 4. Free flow of capital } \\
\text { 5. Free flow of skilled labour } \\
\text { Two important components: } \\
\text { 6. Priority integration sectors } \\
\text { 7. Food, agriculture and forestry }\end{array}$ & $\begin{array}{l}\text { Term 'unified market' with 'seamless } \\
\text { movement' (of goods, services, investment, } \\
\text { capital and skilled labour) is introduced with } \\
\text { the following core elements: } \\
\text { 1. Trade in goods } \\
\text { 2. Trade in services } \\
\text { 3. Investment environment } \\
\text { 4. Financial integration, financial } \\
\text { inclusion, and financial stability } \\
\text { 5. Facilitating the movement of skilled } \\
\text { labour and business visitors } \\
\text { 6. Enhancing participation in global value } \\
\text { chains }\end{array}$ \\
\hline
\end{tabular}

Source: Official Document of the 2015 and 2025 AEC Blueprints

The details of these characteristic are not similar, although certain areas of consideration are identical, such as goods, services, investment, capital, financial or skilled labour and their movements; nonetheless, whole terms have changed. The older blueprint used the terms 'free flow of goods,' 'free flow of services,' 'free flow of investment,' 'free flow of capital,' and 'free flow of skilled labour,' whereas the new blueprint describes these concepts as the 'seamless movement of goods, services, investment, capital, and skilled labour.' Accordingly, these terms are elaborated as 'trade in goods,' 'trade in services,' 'investment environment,' 'financial integration, financial inclusion, financial stability,' and 'facilitating the movement of skilled labour and business visitors.' The term 'free flow', which reflects the fundamental freedom 
presented by trade liberalization, has been eliminated. This term is, apparently, no longer suitable given the current climate within the ASEAN, and, thus, it would seem that the concept of market integration has been abolished. This means a reduction of free movement in the context of regional trade; nonetheless, free movement has not been removed completely - the new blueprint still facilitates the movement of goods, services, capital, investment and labour through introducing the term 'seamless movement.' This might explain the change to the umbrella term from 'a single market and production base' to 'a highly integrated and cohesive economy.'

Furthermore, due to a customs union incorporating a tariff policy regarding imports, a detailed comparison, presented in Table 5, between the concepts of 'free flow of goods' and 'trade in goods' is necessary to differentiate the old and new characterizations of the AEC.

Table 5

Details of 'Free Flow of Goods' and 'Trade in Goods'

\begin{tabular}{|l|l|}
\hline \multicolumn{1}{|c|}{ 2015 AEC Blueprint } & \multicolumn{1}{c|}{ 2025 AEC Blueprint } \\
A single market and & A highly integrated and cohesive economy \\
\hline $\begin{array}{l}\text { Free flow of goods base } \\
\text { - Elimination of tariffs using } \\
\text { the Common Effective }\end{array}$ & $\begin{array}{l}\text { Trade in goods } \\
\text { - Eliminate border and behind-the-border } \\
\text { regulatory barriers that impede trade }\end{array}$ \\
ASEAN Free Trade Area & - Strengthening ASEAN Trade in Goods \\
- Elimination of non-tariff & - Agreement \\
barriers & Simplifying and strengthening the \\
- Rule of origin & implementation of rule of origin \\
- Trade facilitation & Accelerating and deepening the \\
- Customs integration & implementation of trade facilitation \\
- ASEAN single window & measures \\
- Standards and technical & - The term 'customs integration' has been \\
barriers to trade & eliminated \\
& - Key measures include an ASEAN Single \\
& Window, Trade Repositories, customs \\
& procedures simplification, Authorized \\
& Economic Operator, Self-Certification \\
program, Public-Private sector \\
cooperation, Non-Tariff Measures \\
elimination, facilitative standards and \\
conformity \\
\hline
\end{tabular}

Source: Official Document of the 2015 and 2025 AEC Blueprints 
Table 5 shows that comparable elements refer to similar concepts, such as FTA, trade in goods, non-tariff barrier, rule of origin, and trade facilitation. However, the term 'customs integration' has been eliminated and new terms have been introduced, such as trade repositories, authorized economic operator, self-certification program, and cooperation between public and private sectors. Although the terms 'free flow of goods' and 'trade in goods' represent similar concepts, the omission of the term 'free flow' introduces doubts. The following section explores this concern, along with the respective relationships of the two blueprints with the terms 'customs union' and 'single market.'

\subsection{The Term Does Matter: Conceptual and Relational Analysis}

By applying a conceptual analysis to the theory of economic integration, the term 'single market' is recognized as the first key characteristic in the 2015 AEC blueprint; however, the term does not exist in the 2025 AEC blueprint. In the 2015 AEC blueprint, the term is stipulated as a characteristic of the AEC, connoting a connection with the European model of economic integration. The term is often associated with the EU due to ubiquitous discussion of the European single market. Additionally, economicintegration theory developed through the long experience of European economic integration: Balassa's 'The Theory of Economic Integration', based on the European experience, provided a foundational framework for economic-integration theory. His concept has substantially aided scholars attempting to describe economic integration in other regions.

Furthermore, the essential factor of a single market is the principle of free movement, as formulated by economic-integration theory. Therefore, the free flow of goods, services, capital and labour are important elements in a single market. The 2015 AEC blueprint saw this principle as a core element of an ASEAN single market. However, the term 'free flow' has been omitted from the 2025 blueprint and, thus, so too has the notion of a single market. To proceed to a single market, a customs union should implement free-flow conditions, the free flow of goods, services, capital, and labour being fundamental factors in a single market. In other words, the absence of free-flow conditions precludes the possibility of a single market. 
It is worth noting that the term 'customs union' cannot be found in either blueprint. Nonetheless, relational analysis reveals the concept of a 'customs union' exists because the term 'single market' is stipulated in the 2015 AEC blueprint, meaning a customs union would have to be established to build the foundations for a single market. That is, the implicit concept that is the term 'single market' connoting fulfilment of the concept of a 'customs union' has been extracted.

As explained by economic-integration theory, a single market is a customs union featuring the free flow of goods, services, capital and labour. In other words, a single market could not be established without first developing a customs union. Thus, if the goal is a single market, a customs union also becomes a requirement. Although the term 'customs union' was not written explicitly in the 2015 AEC blueprint 2015, it is implied by the use of the term 'single market' as part of the first key characteristic of the AEC. This leads to the assumption of the creation of a customs union in the ASEAN leading to the establishment of a single market, even though the term 'customs union' is not used in the official document.

Table 6 compares aspects of economic-integration theory developed into a coding framework with the AEC blueprints. 
Table 6

Implementation of Theoretical Terms in each AEC Blueprint

\begin{tabular}{|c|c|c|}
\hline $\begin{array}{c}\text { Essential Terms } \\
\text { as Coding } \\
\text { Framework } \\
\end{array}$ & $\begin{array}{l}2015 \text { AEC Blueprint } \\
\text { (2007-2015) }\end{array}$ & $\begin{array}{l}2025 \text { AEC Blueprint } \\
\text { (2016-2025) }\end{array}$ \\
\hline $\begin{array}{l}\text { Free-Trade Area } \\
\text { (FTA) } \\
\text { Rule of origin as } \\
\text { a pillar }\end{array}$ & $\begin{array}{l}\text { - } \text { Term FTA is used } \\
\text { - FTA is implemented } \\
\text { through the Common } \\
\text { Effective Preferential } \\
\text { Tariff for ASEAN Free } \\
\text { Trade Area } \\
\text { - } \text { Rule of origin is } \\
\text { applied }\end{array}$ & $\begin{array}{l}\text { - Term FTA is not used, but } \\
\text { FTA scheme is essentially } \\
\text { implemented through the } \\
\text { ASEAN Trade in Goods } \\
\text { Agreement because rule of } \\
\text { origin is applied in ATIGA }\end{array}$ \\
\hline $\begin{array}{l}\text { Customs Union } \\
\text { Common } \\
\text { External Tariff } \\
\text { (CET) as a pillar }\end{array}$ & $\begin{array}{l}\text { - No term 'customs } \\
\text { union' } \\
\text { - Term 'customs } \\
\text { integration' has a } \\
\text { different definition } \\
\text { - Customs union not } \\
\text { implemented } \\
\text { - CET is not applied } \\
\text { - Customs union may } \\
\text { have a chance to be } \\
\text { established given the } \\
\text { single market concept } \\
\text { is included }\end{array}$ & $\begin{array}{l}\text { - No term 'customs union' } \\
\text { - Term 'customs integration' } \\
\text { is omitted } \\
\text { - Customs union may not } \\
\text { have a chance to be } \\
\text { established given the single } \\
\text { market concept is abolished } \\
\text { in the new blueprint } \\
\text { - Likely customs union will } \\
\text { not be implemented }\end{array}$ \\
\hline $\begin{array}{l}\text { Single Market } \\
\text { Freedom } \\
\text { principle as a } \\
\text { pillar: the free } \\
\text { flow of goods, } \\
\text { services, capital } \\
\text { and labour }\end{array}$ & $\begin{array}{l}\text { - Term 'single market' } \\
\text { exists } \\
\text { - Single market could not } \\
\text { be achieved } \\
\text { - The principle of the } \\
\text { free flow of goods, } \\
\text { services, capital, and } \\
\text { labour is clearly stated } \\
\text { as a core element of a } \\
\text { single market } \\
\text { - ASEAN added a term: } \\
\text { 'free flow of } \\
\text { investment' aims to } \\
\text { attract foreign direct } \\
\text { investment and intra- } \\
\text { ASEAN investment }\end{array}$ & $\begin{array}{l}\text { - Term 'single market' is } \\
\text { abolished } \\
\text { - Term 'unified market' is } \\
\text { introduced in paragraph } 7 \text { as } \\
\text { part of 'a highly integrated } \\
\text { and cohesive economy' } \\
\text { - The principle of the free } \\
\text { flow of goods, services, } \\
\text { capital, investment and } \\
\text { skilled labour is not stated } \\
\text { anymore } \\
\text { - The term 'seamless } \\
\text { movement' is introduced to } \\
\text { describe the movement of } \\
\text { goods, services, capital, } \\
\text { investment and skilled } \\
\text { labour }\end{array}$ \\
\hline
\end{tabular}

Source: Author's Summary and Analysis 
The term 'customs integration' is mentioned in the 2015 AEC blueprint as describing the pursuit of the free flow of goods. The word 'integration' might be interpreted as 'union' in this context. However, the 2015 AEC blueprint presents a different context. This blueprint explained the term 'customs integration' as covering a certain strategic plan aimed at

(a) integrating customs structures; (b) modernizing tariff classification, customs valuation and origin determination and establishing ASEAN e-Customs; (c) smoothening customs clearance; (d) strengthening human resources development; (e) promoting partnership with relevant international organizations; (f) narrowing the development gaps in customs; and (g) adopting risk management techniques and audit-based control (PCA) for trade facilitation (ASEAN Secretariat, 2008, p. $8)$.

That is, the concept of 'customs integration' used in the 2015 AEC blueprint was not related to the notion of a customs union. A customs union describes a common tariff policy toward external players, while, in this case, the term 'custom integration' describes customs structures, tariff classifications, clearances, and risk management but not a CET. Therefore, 'customs integration' does not necessarily connote a customs union; instead, it mainly describes organizational development and management rather than a policy of CET implementation in service of deepened economic integration.

\subsection{ASEAN and EU: a Lesson Learnt}

This section compares the economic integration processes in the ASEAN and the EU to distinguish patterns of economic integration. The EU was selected because it has more experience of integration, specifically in the economic area, it has an influential role in the development of economic-integration theory, and it is considered the region with the most substantial economic integration and institutional development.

\subsubsection{Current ASEAN Economic Integration}

Based on economic-integration theory, ASEAN reached the FTA stage following implementation of the ASEAN FTA (AFTA) in 1992. The AFTA was established by agreeing to the Common Effective Preferential Tariff (CEPT) Scheme for the ASEAN 
Free Trade Area in Singapore on the 29th of January 1992. This agreement was initially signed by six member states - Brunei, Indonesia, Malaysia, the Philippines, Singapore and Thailand (ASEAN-6). With this agreement, ASEAN agreed to create an AFTA to accelerate the liberalization of intra-ASEAN trade and investment using the CEPT. Under this scheme, ASEAN committed to reducing tariffs from $20 \%$ to between $0 \%$ and $5 \%$. It covered all manufactured products except agricultural products (Agreement on the Common Effective Preferential Tariff Scheme for the ASEAN Free Trade Area, 1992).

However, agricultural products were included in the tariff reduction schedule established by the 1995 protocol for amending the CEPT (Protocol to Amend the Agreement on the Common Effective Preferential Tariff Scheme for the ASEAN Free Trade Area, 1995). When four new countries joined ASEAN - Cambodia, Laos, Myanmar and Vietnam - the agreement was revised by another protocol to amend the CEPT in service of the elimination of import duties. Under this agreement, the six original member states would have to eliminate import duties by no later than the 1st of January, 2010, while the four new member states would have until the 1st of January, 2015 (Protocol to Amend the Agreement on the Common Effective Preferential Tariff Scheme for the ASEAN Free Trade Area for the Elimination of Import Duties, 2003).

Currently, the ASEAN Trade In Goods Agreement (ATIGA) provides tariff reductions or removals. This replaced the original AFTA. However, the ATIGA is essentially an FTA agreement in which rule of origin is implemented. The provisions under ATIGA show that it can be considered to conform to FTA stage of economic integration because there are no other provisions in ATIGA presenting the idea of a customs union or single market; for example, there are no articles about a CET (ASEAN Trade in Goods Agreement, 2009).

\subsubsection{Current EU Economic Integration: A Customs Union, A Single Market and Economic Policy Coordination}

The EU has implemented deeper integration by establishing a single market and monetary union; this means a customs union has been implemented. In 2018, the EU celebrated the 50th anniversary of its customs union. The uniform system of import and export handling, including the transit system, is implemented through the Union Customs 
Code. There are no customs duties between member countries, while uniform customs duties have been imposed on imports from outside the union. Import duty is paid at the first port of entry. Furthermore, imported goods circulating between member countries are not inspected and are not charged further duties. The EU considers the customs union to be essential for the establishment of a single market and monitors the customs union through the EU Commission (European Commission, n.d.a).

Additionally, the EU established a single market; that is, a contiguous area with no regulatory obstacles and no internal borders, enabling the free movement of goods, services, capital and people. This aims to stimulate trade, improve efficiency, create competition, increase quality and reduce costs, ultimately leading to growth and easy business relationships (European Commission, n.d.b). However, there are still some exceptions regarding the free movement of goods, generally in the context of commodities presenting concerns in the areas of public health, environment and consumer protection. To enhance movement in these areas, the EU has enhanced legislative certainty by harmonizing technical regulations so that risks are reduced, and the movement of those goods is both smooth and secure (Committee for European Construction Equipment, n.d.).

In addition to its single market, the EU implemented the Economic and Monetary Union in 1991 through the Maastricht Treaty. The Economic and Monetary Union coordinates economic policymaking among members states, including fiscal policy and independent monetary policy; it also creates uniform rules for financial institutions and is responsible for the Euro. Monetary policy and financial institutions are governed by a supranational body, the European Central Bank, while economic policy is coordinated by the Council of the EU. The performance and compliance of these institutions are monitored by the European Commission (European Commission, n.d.c).

\subsubsection{Comparative Regionalism of the ASEAN and the EU}

Comparing the economic-integration of the ASEAN and the EU indicates that the ASEAN is still at the FTA stage, with some tariffs for trade between members remaining, as indicated by the tariff schedules in Annex 2 of the ATIGA (ASEAN Trade in Goods Agreement, 2009). Perfect free trade imposes zero tariffs on trade between participating 
countries. However, member countries can impose duties on commodities from the sensitive list or non-inclusion list. Based on the 2025 blueprint and the current status of integration, it can be assumed that the ASEAN will remain at the FTA stage until at least 2025. Table 7 generally compares the levels of economic integration of the ASEAN and the EU.

Table 7

Regional Comparison of the ASEAN and the EU: Economic-Integration

Perspective

\begin{tabular}{|c|c|c|}
\hline Integration Stage & EU & ASEAN \\
\hline $\begin{array}{l}\text { Free Trade Area } \\
\text { (FTA) }\end{array}$ & $\begin{array}{l}\text { - FTA is implemented } \\
\text { with zero tariff for trade } \\
\text { within the union }\end{array}$ & $\begin{array}{l}\text { - FTA is implemented under } \\
\text { the ATIGA scheme by } \\
\text { implementing rule of origin } \\
\text { - Not all tariffs are zero, but } \\
\text { most tariffs have been } \\
\text { reduced }\end{array}$ \\
\hline Customs Union & $\begin{array}{l}\text { - Customs union is } \\
\text { implemented with a } \\
\text { common external tariff }\end{array}$ & $\begin{array}{l}\text { - Customs union not } \\
\text { implemented } \\
\text { - No common external tariff }\end{array}$ \\
\hline Single Market & $\begin{array}{l}\text { - Single market is } \\
\text { implemented } \\
\text { - Embraces the principle } \\
\text { of freedom of } \\
\text { movement of goods, } \\
\text { services, capital and } \\
\text { people } \\
\text { - Only exception for } \\
\text { goods movement } \\
\text { concerns risky } \\
\text { commodities }\end{array}$ & $\begin{array}{l}\text { - No single market } \\
\text { - No term 'free flow' (freedom } \\
\text { principle) to describe the } \\
\text { movement of services, } \\
\text { capital and people } \\
\text { - Full freedom is limited, but } \\
\text { movement is facilitated as } \\
\text { much as possible } \\
\text { - Introduction of new terms } \\
\text { 'unified market' and } \\
\text { 'seamless movement' but the } \\
\text { characteristics do not meet } \\
\text { the criteria of single market }\end{array}$ \\
\hline $\begin{array}{l}\text { Complete } \\
\text { Economic } \\
\text { Integration/ } \\
\text { Complete } \\
\text { Economic Union }\end{array}$ & $\begin{array}{l}\text { - Common monetary and } \\
\text { fiscal policies are } \\
\text { applied and harmonized } \\
\text { - Supranational authority } \\
\text { for common policies: } \\
\text { European Central Bank, } \\
\text { The Council of the EU, } \\
\text { the European } \\
\text { Commission. }\end{array}$ & $\begin{array}{l}\text { - No common monetary and } \\
\text { fiscal policies } \\
\text { - No supranational authority } \\
\text { managing economic policies }\end{array}$ \\
\hline $\begin{array}{l}\text { Complete } \\
\text { Political Union }\end{array}$ & - Not applicable & - Not applicable \\
\hline
\end{tabular}

Source: Author's Analysis 
No longer aiming to develop into a single market, the ASEAN appears to have modified its ambitions. Instead, by introducing the terms 'unified market' and 'integrated and cohesive economy,' the ASEAN shows it is still searching for a suitable formula for deepening its economic integration. In the economic-integration context, the terms 'unified,' 'integrated' and 'cohesive' appear closely related to the terms 'single' or 'common', as is the term 'seamless movement' compared to 'free flow.' Not utilizing the terms 'single market' and 'free flow' indicates the ASEAN's efforts to avoid imitating the EU economic-integration model. These moves appear to be made in service of providing a clear picture of ASEAN economic integration. Not doing so might lead to a misunderstanding of the nature of the AEC.

Although the single market term and concept have been eliminated from the 2025 blueprint, the ASEAN incorporates a 'single market-like' concept through the term 'unified market.' Additionally, the ASEAN introduces a 'free flow-like' concept with the term 'seamless movement' to describe facilitation of the movement of goods, services, investment, capital and skilled labour within the ASEAN. The changes to the terms indicate that the ASEAN wants to avoid directly copying the EU economic-integration model and, thus, develops its own concept of a 'unified market' with 'seamless movement' of goods, services, investment, capital and skilled labour. These new terms seem to be closely connected to the 2015 blueprint's terms 'single market' and 'free flow.' However, it can be inferred that the ASEAN will not follow the concept of a single market as applied in the EU context. Unlike the EU single-market concept, with its prerequisite customs union, the 2025 blueprint describes the ASEAN's 'unified market' concept as concerning trade in goods consisting simply of the ATIGA's FTA incorporating rule of origin and trade facilitation. However, by not addressing the concept of a customs union, the 2025 blueprint shows that the ASEAN continues to limit economic integration to the FTA stage.

\subsubsection{The Pattern of ASEAN Economic Integration}

By comparing economic integration, the pattern of ASEAN economic integration can be identified. The ASEAN's implementation of an FTA through ATIGA shows the commitment to reducing tariff and non-tariff barriers to intra-trade relations. 
Nevertheless, the absence of a customs union indicates less commitment to integration.

Significantly, the elimination of a single market concept confirms that the ASEAN has decreased its economic-integration ambitions. Consequently, the ASEAN will remain at the FTA stage until at least 2025. Although, ASEAN introduces the concept of 'unified market' with 'seamless movement' creating an image as 'single market-like' with 'free flow-like', those terms do not meet the criteria of 'single market' with 'free flow' concept as specified in the theories of economic integration.

Without a customs union, every member state can impose different external tariffs, meaning the ASEAN will tend toward open regionalism as the core of an outward-looking policy because the main trading partners of its member states are outside the region. It also means that every member state can arrange an individual free-trade agreement with other non-ASEAN countries. However, Plummer (2006) warned that with more free-trade agreements between individual member states and parties outside the ASEAN, it would become more difficult to integrate the market and create a customs union.

\subsubsection{Alternatives to the Free-Trade Area}

Moving beyond the FTA stage has been suggested by scholars as a prerequisite for integration. Plummer (2006) suggested that the potential benefit of a customs union makes it necessary for the AEC's success. To improve integration, the optimal regional tariff can be determined through policy coordination and calculation. Basu Das, Sen and Srivastava (2015) presented possibilities such as an FTA with zero tariffs, a customs union with 2-5\% CET which wouldn't include Singapore, and a customs union with $0 \%$ CET which would include Singapore. However, such an agreement is complicated by the divergent tariff schedules among ASEAN member states. For example, countries for whom most tariffs are zero would be reluctant to increase tariffs to meet the CET. For this situation, the ASEAN-X formula can be applied in which not all members join the arrangement. As proposed by Andic, Andic and Dosser (1971), the ASEAN could also consider a sectoral approach to proceeding beyond the FTA. The customs union could be initiated by clustering the customs union based on a sectoral approach, rather than having a customs union for all sectors or commodities; this would also incorporate an FTA for 
common industries within the ASEAN. This model's emphasis on development creation rather than trade creation could form a central concern for the ASEAN.

Additionally, economic integration could consider geographical considerations, as introduced by El-Agraa (2011). Hence, this study considers a sub-regional customs union. Consisting of archipelago and continent, the ASEAN could develop a sub-regional customs union based on geographical considerations. For example, Cambodia, Laos, Myanmar, Vietnam, Thailand and peninsular Malaysia could be grouped into a subregional customs union. Another sub-regional customs union would be Borneo, including Brunei, Indonesia (Kalimantan) and Malaysia (Sarawak). The provinces outside Borneo would not be included in this geographical consideration. This model is similar to the ASEAN-X formula; however, it considers geographical location as a practical reason for goods circulation. The implementation of these two customs unions would contribute to the pursuit of welfare in the region.

Pelkmans' concepts of FTA-plus and deep-and-comprehensive FTA (2016) remain at the FTA level, having not proceeded to the customs union level. Although the FTA is built upon by measures such as tariffs and quota, such as those specified by the positive integration features described in Section 2, these motions do not take integration beyond the FTA stage, specifically because a CET, a central feature of a customs union, is still not implemented.

\section{CONCLUSION}

The 2015 AEC blueprint has been replaced by the 2025 AEC blueprint. The 2015 blueprint indicated that a single market was the ASEAN's ultimate goal through stipulating the terms 'single market' and 'free flow' (of goods, service, capital and labour). The freedom of movement principle is the main feature of a single market. Although the term 'customs union' was not explicit in the 2015 blueprint, it could be inferred from the term 'single market', a concept which implicitly contains the customs union concept. Use of the term 'single market' has driven some scholars to discuss a customs union in the context of the ASEAN. Scenarios for the implementation of a customs union have been discussed, a customs union being considered a necessary step 
toward the establishment of a single market. That is to say that a single market cannot be achieved without first establishing a customs union.

The 2025 AEC blueprint features significant changes. First, the term 'single market' has been omitted from it, along with the principle of freedom of movement of goods, service, capital, investment and labour. The elimination of the term 'single market' and the term 'free flow' suggest a change to the ambitions for economic integration of the ASEAN, the term 'free flow' being the defining characteristic of the single market. These changes suggest the ASEAN is no longer pursuing a single market as the goal of its economic integration. The introduction of the term 'unified market' and the term 'seamless movement' in the new blueprint does not meet the 'single market' and 'free flow' requirements.

Moreover, the 2025 blueprint does not contain the concept of a customs union either explicitly or implicitly. There is no mention of a CET, this being the main feature of a customs union. The tariff discussed under 'trade in goods' - ATIGA -refers to FTA implementation, with rule of origin as a central mechanism. Therefore, ATIGA operates at the FTA stage of economic integration, confirming that the 2025 blueprint is limited to this stage of integration. That is, the ASEAN does not appear likely to proceed to a customs union or a single market, despite possibilities offered by certain scholars. Still, it is possible for ASEAN to move beyond FTA by executing one or more customs-union scenarios; these include taking a sectoral approach, using the ASEAN-X model or creating subregional customs unions through geographical grouping.

Lessons can be derived from this analysis. First, the terms used in the blueprint are important because they indicate customs union and single market are considered unfeasible goals and ASEAN has adjusted its targets for economic integration accordingly. Second, ASEAN economic integration likely follow the pattern of open regionalism, rather than developing a customs union as a closed trade block by implementing a CET for non-ASEAN countries; nonetheless, plausible customs union models have been suggested. 


\section{LIMITATION AND SUGGESTION}

This study mainly relied on both the 2015 and 2025 AEC blueprint as the 'text' for content analysis to comprehend the concept of ASEAN economic integration. It did not cover the interview to the conceptors of the blueprints to deeply understand the change of the blueprint. However, the blueprints as official documents signed by ASEAN leaders are reliable sources. Hence, the content analysis was considered adequate to analyze the change of the concept in the blueprints. Further research by using interview or focus group discussion with the think thank of the blueprint could enrich the study of ASEAN economic integration.

\section{ACKNOWLEDGEMENT}

The author would like to thank the Directorate General of Customs and Excise, Ministry of Finance of the Republic of Indonesia (MOF-RI) for granting the opportunity to pursue $\mathrm{PhD}$ program and the Indonesia Endowment Fund for Education (Lembaga Pengelola Dana Pendidikan/LPDP) MOF-RI, from which the author has received scholarship.

\section{REFERENCES}

Agreement on the Common Effective Preferential Tariff Scheme for the ASEAN Free Trade Area. Jan. 28, 1992. Retrieved June 6, 2020, from https://asean.org/?static post=agreement-on-the-common-effective-preferentialtariff-cept-scheme-for-the-asean-free-trade-area-afta

Andic, F., S. Andic, \& D. Dosser. (1971). A theory of economic integration for developing countries. London: George Allen \& Unwin Ltd.

ASEAN Secretariat. (2008). ASEAN Economic Community Blueprint. Jakarta: ASEAN Secretariat.

ASEAN Secretariat. (2015). ASEAN Economic Community Blueprint 2025. Jakarta: ASEAN Secretariat.

ASEAN Trade in Goods Agreement. Feb. 26, 2009. Retrieved June 6, 2020, from https://www.asean.org/storage/images/2013/economic/afta/atiga\%20interactive $\%$ 20rev4.pdf

Balassa, B. (1961). The theory of economic integration. New York: George Allen \& Unwin Ltd. 
Basu Das, S., Sen, R., \& Srivastava, S. (2015). AEC Vision Post-2015: Is an ASEAN customs union feasible? ISEAS Economics Working Paper, No.2015-1.

Carley, K. (1994). Content analysis. In R.E. Asher (Ed.). The Encyclopedia of Language and Linguistics. Oxford: Pergamon Press.

Committee for European Construction Equipment. (n.d.). European single market. Retrieved June 6, 2020, from https://www.cece.eu/industry-and-market/europeansingle-market

Downe-Wamboldt, B. (1992). Content analysis: Method, applications, and issues. Health Care for Women International, 13(3), 313-321.

El-Agraa, A.M. (2011). The European Union: Economics and policies. Cambridge: Cambridge University Press.

European Commission. (n.d.a). EU customs union - unique in the world. Retrieved June 6, 2020, from https://ec.europa.eu/taxation_customs/facts-figures/eu-customsunion-unique-world_en

European Commission. (n.d.b). The European single market. Retrieved June 6, 2020, from https://ec.europa.eu/growth/single-market en

European Commission. (n.d.c). What is the Economic and Monetary Union? (EMU). Retrieved June 6, 2020, from https://ec.europa.eu/info/business-economyeuro/economic-and-fiscal-policy-coordination/economic-and-monetaryunion/what-economic-and-monetary-union-emu en

Folger, J. P., Hewes, D. E., \& Poole, M. S. (1984). Coding social interaction. In B. Dervin \& M. J. Voigt (Eds.). Progress in communication sciences, Volume IV (pp. 115161). Norwood, NJ: Ablex.

Hickey, G. \& Kipping, C. (1996). Issues in research: A multi-stage approach to the coding of data from open-ended questions. Nurse Researcher, 4, 81-91.

Hosny, A.S. (2013). Theories of economic integration: A survey of the economic and political literature. International Journal of Economy, Management and Social Sciences, 2(5), 133-155.

Hsieh, H.F. \& Shannon, S.E. (2005). Three approaches to qualitative content analysis. Qualitative Health Research, 15(9), 1277-1288.

Krippendorff, K. (2019). Content analysis: An introduction to its methodology. 4th Ed. Los Angeles: Sage.

Mayring, P. (2000). Qualitative Content Analysis. Qualitative Social Research, 1(2). 
Pelkmans, J. (2016). The ASEAN Economic Community: A conceptual approach (Integration through Law: The Role of Law and the Rule of Law in ASEAN Integration). Cambridge: Cambridge University Press.

Plummer, M. G. (2006). An ASEAN customs union? Journal of Asian Economics, 17, 923-938.

Potter, W. J., \& Levine-Donnerstein, D. (1999). Rethinking validity and reliability in content analysis. Journal of Communication Research, 27:3, 258-284.

Protocol to Amend the Agreement on the Common Effective Preferential Tariff Scheme for the ASEAN Free Trade Area. Dec. 15, 1995. Retrieved June 6, 2020, from https://asean.org/?static_post=protocol-to-amend-the-agreement-on-the-commoneffective-preferential-tariff-scheme-for-the-asean-free-trade-area

Protocol to Amend the Agreement on the Common Effective Preferential Tariff Scheme for the ASEAN Free Trade Area for the Elimination of Import Duties. Jan. 31, 2003. Retrieved June 6, 2020, from https://asean.org/?static_post=protocol-to-amendthe-agreement-on-the-common-effective-preferential-tariff-cept-scheme-for-theasean-free-trade-area-afta-for-the-ilimination-of-import-duties

Schreier, M. (2012). Qualitative content analysis in practice. Los Angeles; London: Sage Publications.

Viner, J. (1950). The customs union issue. New York: Carnegie Endowment for International Peace. 